\title{
Öğretim Üyelerinin Öğretim Sürecinde Kullandıkları Kaynaklar ${ }^{1}$
}

Resources Used by Faculty Members in the Teaching Process

\section{Hülya SERT-ÇELIKK², Kübra UZUN-YAZICI ${ }^{3}$, Menekşe Seden TAPAN-BROUTIN ${ }^{4}$, Gül KALELİ-YILMAZ ${ }^{5}$}

\begin{abstract}
Öz
$\mathrm{Bu}$ araştırmada öğretim üyelerinin öğretim sürecinde kullandıkları kaynakların incelenmesi amaçlanmıştır. Bu araştırma durum çalışması yöntemiyle yürütülmüştür. Araştırmanın çalışma grubunu, 2018-2019 eğitim-öğretim yılı bahar döneminde Marmara Bölgesi'ndeki bir devlet üniversitesi eğitim fakültesinde matematik eğitimi anabilim dalındaki altı öğretim üyesi oluşturmaktadır. Bu araştırmada amaçlı örnekleme yöntemlerinden tipik durum örneklemesi kullanılmıştır. Veriler yarı- yapılandırılmış mülakatlardan elde edilmiştir. Elde edilen veriler, içerik analizi tekniğiyle çözümlenmiştir. Yapılan analizlerden elde edilen veriler incelenerek belirlenen tema, kategori ve kodlar yeniden yorumlanmıştır. Araştırma sonucunda, öğretim üyelerinin derslerini Yükseköğretim Kurulu (YÖK) tarafından hazırlanan müfredata göre yapılandırdıklarını ve ders içeriklerinde yapılan değişikliklere göre derslerini güncellediklerini dile getirmişlerdir. Ayrıca akademik kitap, akademik makale ve ders kitabı ile Google akademik, öğretim içerikli videolar öğretim üyelerinin en çok kullandıkları kaynaklardandır. Öğretim üyelerinin öğretim tarzlarını etkileyen en önemli faktör geçmiş eğitim yıllarındaki derslerine giren bir öğretmenleri ve alanda yazılmış öğretim kitapları olmuştur. Öğretim üyelerinin hangi kaynağı hangi sebeple reddedip hangi sebeple kabul etme kriterleri incelenebilir.
\end{abstract}

Anahtar Kelimeler

Kaynak kullanımı Öğretim üyesi Öğretim süreci

\section{Abstract}

In this study, it is aimed to investigate the resources used by faculty members in the teaching process. This research was conducted with the case study method. The working group of the research consists of six faculty members in the department of mathematics education at a state university education faculty of the 2018-2019 academic year. Typical case sampling, one of the purposeful sampling methods, was used in this study. The data were obtained from semistructured interviews and analyzed by content analysis technique. The themes, categories and codes determined by analyzing the data obtained from the analyzes were reinterpreted. As a result of the research, the faculty members stated that they structured their lessons according to the curriculum prepared by YOK, updated their courses according to the changes made in the course content. In addition, academic books, academic articles, textbooks, Google academic, instructional videos are among the most used resources by faculty members. The most important factor affecting the teaching styles of the faculty members was teachers who attended the lessons of the previous academic years and the teaching books written in the field. The criteria for which sources the faculty members reject and accept for what reason can be examined.

\begin{tabular}{lll}
\hline Başvuru Tarihi/Received & Kabul Tarihi /Accepted & | Araştırma Makalesi / Research Article $\mid$ \\
19.02.2021 & 16.04 .2021
\end{tabular}

\section{Suggested APA Citation/Önerilen APA Atıf Biçimi:}

Uzun-Yazıcı, K., Sert-Çelik, H., Tapan-Broutın, M. S., \& Kaleli-Yılmaz, G. (2021). Resources used by faculty members in the teaching process. Manisa Celal Bayar University Journal of the Faculty of Education, 9(1), 68-80. https://doi.org/10.52826/mcbuefd.883478.

\footnotetext{
${ }^{1} \mathrm{Bu}$ çalışmada 2020 yılı öncesine ait veriler kullanıldığı yazarlar tarafından beyan edildiği için etik kurul raporu gerekmemektedir.

${ }^{2}$ Sorumlu Yazar, Öğretmen, MEB, İçmeler İ.C.K.K.A Ortaokulu, Muğla, TÜRKIYYE; (iD https://orcid.org/0000-0002-5021-7449

3 Öğretmen, MEB, Semiha Mustafa Özer Ortaokulu, Bursa, TÜRKIYE; (D https://orcid.org/0000-0003-4174-0227

4 Doç. Dr., Bursa Uludağ Üniversitesi, Eğitim Fakültesi, Matematik ve Fen Bilimleri Eğitimi Bölümü, Bursa, TÜRKIYYE; (iD https://orcid.org/0000-0002-1860-852X

${ }^{5}$ Doç. Dr., Bursa Uludă̆ Üniversitesi, Eğitim Fakültesi, Matematik ve Fen Bilimleri Eğitimi Bölümü, Bursa, TÜRKIYE; (D) https://orcid.org/0000$\underline{0002-8567-3639}$
} 


\section{GİRIŞ}

Matematik öğretim durumlarını planlama ve düzenleme yeterlik alanı; matematik öğretim sürecini planlama, amaca uygun ortamlar düzenleme, araç gereç hazırlama ve teknolojik kaynaklardan yararlanma durumudur. Aynı zamanda öğrencilerin duyuşsal özelliklerini geliştirebilme, öğrencilerin gereksinimleri ve özelliklerini dikkate alan uygulamalar yapabilme sürecini kapsamaktadır (Millı̂ Eğitim Bakanlı̆̆ı, 2008). Bu uygulamaların düzenleyicileri olan öğretmenler öğretim programı, ders kitabı ve yardımcı kaynaklar ile iç içedirler ve öğretmenler hem sınıf içinde hem de sınıf dışında kaynakları seçer, düzenler ve yeni kaynaklar oluştururlar. Öğretmenlerden öğretim sürecinde araç-gereç, materyal ve kaynak kullanabilme ve öğretim sürecini planlama becerisine sahip olmaları beklenmektedir (Association of Mathematics Teacher Educators, 2017; Council of Chief State School Officers, 2013; Gözalan- Çiçek, 2016; MEB 2008, 2017; National Board for Professional Teaching Standards, 2016; Sezer, 2020).

İlgili literatür incelendiğinde öğretmenlerin (Pepin, Gueudet ve Trouche, 2013; Baştürk-Şahin, 2015; Özmantar, Dapgın, Çırak-Kurt ve İlgün, 2017; Baştürk-Şahin ve Tapan-Broutın, 2018; Işık- Sarığlu, 2020) ve öğretmen adaylarının (Tapan-Broutın, 2017; Işık-Sarığlu, 2020) kaynak seçimleri, kaynak kullanımları ve ders dokümanı oluşumlarına yönelik yapılan araştırmaların olduğu görülmektedir. Öğretmenlerin kaynaklar ile olan etkileşimleri ve bu etkileşim sonucunda kaynakların ders işlenişi için şekillendirilmesi karmaşık bir süreçtir. Bu süreçte öğretmenler ders kitapları, yardımcı kitaplar, internet sayfaları, zümre tartışmaları, müfredat kaynakları, öğrenci kağıtları, ders içi etkileşimler gibi pek çok kaynak kullanmakta; bu kaynakların kullanımı ile zihinsel öğretim şemalarının birleşmesi ile ise ders dokümanları oluşmaktadır (Tapan-Broutın, 2017). Pepin ve diğerleri (2013) yaptıkları çalışmada öğretmenlerin kaynak kullanımı ve tasarımı bağlamındaki ilişkileri, öğretmenlerin kullandığı kaynaklar ve onların mesleki gelişimleri bağlamındaki ilişkileri ve bu alanda yapılmış çalışmaların teorik çerçevelerini ortaya koymayı amaçlamışlardır. Çalışma sonucunda elde edilen verilere ilişkin öğretmenlerin kolektif çalışmalarının öğretimi yapılandırma sürecinde ve kendi mesleki gelişimlerinde çok önemli bir yere sahip olduğu ortaya çıkmıştır. Adler (2000) çalışmasında matematiksel bağlamda okullarda kullanılan kaynakları incelemiş ve bunların etkililiğini öğretmenin öğretim sürecinde uyguladığı performansa bağlı olduğunu vurgulamaktadır. Cohen, Raudenbush ve Ball (2003) öğretim sürecinde kullanılan kaynakların ve bu kaynakların yönetiminin öğrenci başarısına etki eden bir model ortaya çıkarmışlardır. Öğretimde kullanılan geleneksel kaynakların, öğretim sürecinde kullanılan etmenlere fayda ve zarar verebileceği ve bu etmenlerin birbiriyle, doğal verinin çok değişkenli analizi ile çözümlenemeyecek şekilde ilişkili olduğu için, bu çalışmada, öğretimdeki etmenleri ortaya koyabilecek deneysel bir yöntem önerilmektedir.

Literatürde yapılan çalışmalar genellikle öğretim üyelerinden ziyade öğretmen ve öğretmen adaylarıyla yapılmıştır. Oysaki öğretmenlerin eğitim fakültelerindeki aldıkları- eğitim öğretim süreçlerine bakıldığında derslerine giren öğretim üyelerini rol model aldıkları görülmektedir (Agaç, 2018). Bu nedenle öğretim üyelerinin öğretim sürecinde kullanacakları kaynak sistemleri ve bu kaynak sistemlerinin kullanımı düşünüldüğünde öğretim üyelerinin kitap ve kaynak seçimleri öğretmen adaylarının gelecekteki meslek hayatlarında yol gösterici olacağı düşünülebilir. Bu bağlamda öğretim üyelerinin öğretmen adayları için öğretim yapılandırma sürecinde kullandıkları kitap ve kaynak seçiminin oluşum süreçlerinin nasıl düzenlendiğinin incelenmesi önemlidir. Az sayıda araştırmada öğretim üyelerinin öğretim sürecinde kaynakların incelenmesine çalışılmıştır (Agaç, 2018; Sezer, 2020). Agaç (2018) üniversitelerin matematik eğitimi programlarında görev alan öğretim üyelerinin etkili matematik öğretimine ilişkin yaklaşımlarını ve bilgi kaynaklarını incelediği araştırmasında öğretim üyelerinin çeşitli bilgi kaynaklarından beslendiği sonucuna ulaşılmıştır. Sezer (2020) öğretim üyesinin öğretim sürecinde kaynak kullanımına ilişkin görüşünü incelemeyi amaçlamıştır. Bu amaç doğrultusunda 2017- 2018 eğitim- öğretim yılında yaptı̆̆ görüşme sonucunda öğretim üyesinin öğretim sürecinde belli bir kaynağ1 sistematik olarak takip ettiğini ve tecrübe ile birlikte akademik çalışmalardan yararlandığını sonucuna ulaşmıştır. Aynı zamanda bu öğretim üyesi ders sürecini planlarken öğrenci düzeyi, öğrencilerin ihtiyaçları, öğrenci motivasyonuna dikkat ettiğini ifade etmiştir. Diğer taraftan öğretim üyesi ders planının yıllara veya öğrencilere göre değiştiğini ve ders içeriğini akademik çalışmalar ile internet araştırmalarına göre güncelleme yaptığını belirtmiştir.

| Manisa Celal Bayar University Journal of The Faculty of Education, 2021, Vol. 9, No. 1 | 
$\mathrm{Bu}$ araştırmada matematik ve matematik eğitimi alanındaki öğretim üyelerinin ders içeriğini oluşturma süreçlerine etki eden elemanlar incelenmiştir. Bu bağlamda, araştırmanın problemini "Matematik ve matematik eğitimi alanındaki öğretim üyelerinin ders içeriğini oluşturma sürecindeki kaynaklar nelerdir?" sorusu oluşturmaktadır.

\section{YÖNTEM}

$\mathrm{Bu}$ araştırmada öğretim üyelerinin öğretim sürecinde kullandıkları kaynakları incelemek amacıyla nitel araştırma desenlerinden durum çalışması yöntemi kullanılmıştır. Durum çalışması, araştırılan bir konunun derinlemesine incelenmesine imkân tanır ve eğitimin çeşitli konularını anlamada özellikle ne, nasıl ve niçin sorularına cevap aramada tercih edilen bir yöntemdir (Çepni, 2018; Yin, 2003; Merriam, 1998). Bu araştırmanın durumunu ise öğretim üyelerinin öğretim sürecinde kullandıkları kaynaklar oluşturmaktadır.

\section{Çalışma Grubu}

Araştırmanın çalışma grubunu, 2018-2019 eğitim- öğretim yılı bahar döneminde Marmara Bölgesi'ndeki bir devlet üniversitesi eğitim fakültesinde matematik eğitimi anabilim dalında görev yapan altı öğretim üyesi oluşturmaktadır. Bu araştırmada amaçlı örnekleme yöntemlerinden tipik durum örneklemesi kullanılmıştır. Tipik durum örneklemesindeki amaç, ortalama durumları çalışarak belirli bir alan hakkında fikir sahibi olmaktır (Yıldırım ve Şimşek, 2008). Tipik bir örneklem, "sıradan bir insanı, durumu ya da araştırılan olgu örneğini yansıtmak için seçilir" (Merriam, 1998). Öğretim üyelerinin seçiminde mesleki deneyim, matematik derslerine giriyor olmak, gönüllülük, paylaşıma açıklık ölçütleri dikkate alınmıştır. Araştırmaya katılan tüm öğretim üyelerinin en az on yıllık mesleki deneyimlerinin olması, her birinin öğretim sürecinde kullandıkları kaynaklara ilişkin görüşlerini paylaşmaya açık olmaları, araştırmaya katılmak için gönüllü olmaları ve kolay ulaşılabilirlik kriterleri benimsenmiştir. Araştırmaya katılan öğretim üyelerine ait demografik bilgiler Tablo 1'de verilmiştir.

Tablo 1: Araştırmaya Katılan Öğretim Üyelerine Ait Demografik Bilgiler

\begin{tabular}{cccc}
\hline Kodlar & Cinsiyet & Mesleki deneyim & Uzmanlık alanı \\
\hline ÖÜ1 & Kadın & 20 yıl & Matematik Eğitimi \\
\hline ÖÜ2 & Erkek & 28 yıl & Matematik \\
\hline ÖÜ3 & Erkek & 40 yıl & Matematik \\
\hline ÖÜ4 & Erkek & 31 yıl & Matematik \\
\hline ÖÜ5 & Erkek & 45 yıl & Matematik Eğitimi \\
\hline ÖÜ6 & Kadın & 11 yıl & Matematik Eğitimi
\end{tabular}

Tablo 1 incelendiğinde araştırma, 2'si kadın ve 4'ü erkek olmak üzere 6 öğretim üyesi ile yürütülmüştür. Öğretim üyelerinin mesleki deneyimi, on bir (11) ile kırk beş (45) yıl arasında değişmektedir. Öğretim üyelerinin uzmanlık alanlarına bakıldığında, üç (3) öğretim üyesi matematikte uzman iken üç (3) öğretim üyesi matematik eğitiminde uzmandır.

\section{Verilerin Toplanması}

$\mathrm{Bu}$ araştırmada verilerin elde edilmesinde yarı-yapılandırılmış mülakatlar kullanılmıştır. Yarıyapılandırılmış mülakat, araştırılan problemde derinlemesine soru sorma, cevabın yeterli olmadığı durumlarda sorunun tekrar sorularak cevapların istenilen şekilde tamamlanmasına fırsat vermektedir (Çepni, 2018). Bu bağlamda bu araştırmada öğretim üyelerinin öğretim sürecinde kullandıkları kaynakların incelenip ortaya çıkartılması amaçlandığından verilerin toplanmasında yarı- yapılandırılmış mülakatlar tercih edilmiştir. Yarıyapılandırılmış mülakat soruları matematik eğitimi alanında uzman bir öğretim üyesi ile iki alan uzmanının görüşleri doğrultusunda oluşturulmuştur. Bu araştırmada mülakatın orijinalliğini bozmamak amacıyla öğretim üyelerinden gerekli izinler alındıktan sonra yarı-yapılandırılmış mülakatlardan elde edilen verilerin kaydedilmesinde ses kayıt cihazı kullanılmıştır. 
Yarı yapılandırılmış mülakatta iki alan uzmanı ve matematik eğitimi alanında uzman bir öğretim üyesi tarafından geliştirilen toplam beş açık uçlu soru öğretim üyelerine yöneltilmiştir.

1) Mülakatta öğretim üyelerine aşağıdaki sorular yöneltilmiştir:

2) Derste anlattığınız konulara nasıl karar veriyorsunuz?

3) Derse gitmeden önce anlatacağınız konuları nasıl inşa ediyorsunuz?

4) Anlattığınız konular seneden seneye değişiyor mu? Anlattığınız konularda ya da anlatım tarzınızda seneden seneye değişen farklılıklar var mıdır? Örneklendiriniz.

5) Değişimleri hangi kaynaklardan alıyorsunuz?

6) Sizi en çok etkileyen kaynak, nesne nedir ya da kişi kimdir? Nedenlerini açılayınız.

Yukarıda verilen mülakat soruları, araştırmacılara detaylı bir şekilde, matematik ve matematik eğitimi alanındaki öğretim üyelerinin ders içeriğini oluşturma sürecindeki kaynak kullanımı konusunda yardım etmesi amacıyla yapılandırılmıştır. Sorular incelendiğinde sırasıyla; ders içeriğinin nasıl oluşturulduğu, ders hazırlık süreçlerinin irdelendiği, mesleki yaşantılara binaen değişikliklerin neler olduğu, öğretim süreçlerinde kullandıkları kaynak sistemlerinin nasıl oluştuğu ve öğretim üyelerinin ilham kaynaklarının neler olduğu tespit edilmek istenmiştir.

\section{Veri Analizi}

$\mathrm{Bu}$ araştırmada elde edilen verilerin analiz edilmesinde içerik analizi tekniğinden faydalanılmıştır. İçerik analizinde amaç, mülakat verilerinin derinlemesine incelenmesi sonucunda birbirine benzeyen verileri belirli kodkategori ve temalar çerçevesinde bir araya getirmek ve bunları okuyucunun anlayabileceği bir biçimde düzenleyerek yorumlamaktır (Yıldırım ve Şimşek, 2008; Çepni, 2018). Bu kapsamda mülakat verileri öncelikle yazılı hale dönüştürülmüş, ardından araştırma problemi ile ilgili olmayan kısımlar çıkarılmış ve sadeleştirilen veriler üzerinde kodlamalar yapılmıştır. Oluşturulan kodlar uygun temalarda birleştirilerek tablolar halinde sunulmuştur.

\section{Geçerlik-Güvenirlik}

Araştırmada geçerliği artırmak amacıyla öğretim üyelerinin görüşlerine doğrudan alıntılar yapılarak yer verilmiştir. Verilerin sunumunda, öğretim üyelerinden alınan doğrudan alıntılara ÖÜ1, ÖÜ2, ... , ÖÜ6 kodları ile yer verilmiştir. Buna ek olarak elde edilen veriler iki alan uzmanı tarafından ayrı ayrı kodlanmıştır. Daha sonra matematik eğitimi alanında uzman bir öğretim üyesi ile iki alan uzmanı bir araya gelerek farklılaşma olan kodlamalar üzerinde uzlaşmaya vararak güvenirlik arttırılmaya çalışılmıştır.

Yapılan bu araştırmada "Yükseköğretim Kurumları Bilimsel Araştırma ve Yayın Etiği Yönergesi" kapsamında uyulması belirtilen tüm kurallara uyulmuştur. Yönergenin ikinci bölümü olan "Bilimsel Araştırma ve Yayın Etiğine Aykırı Eylemler" başlı̆ğ altında belirtilen eylemlerden hiçbiri gerçekleştirilmemiştir. Ayrıca, veri toplama süreci 2020 yılı öncesinde tamamlandığından, bu araştırma etik kurul izni gerektirmeyen çalışmalar arasında yer almaktadır.

\section{BULGULAR}

Araştırmanın bu bölümünde veri analizi sonucunda elde edilen bulgulara yer verilmiştir. Yapılan içerik analizi sonucunda görüşler, 5 tema ve 33 kod altında çözümlenmiştir. Elde edilen temalar ve kategorilere göre ayrıştırılan kodlar ve kodlara ait frekans değerleri tablolar halinde sunulmuştur.

Öğretim üyelerinin ders içeriklerini oluştururken kullandıkları kaynaklar ile ilgili "Ders içeriğinin oluşturulması" temasına ait kodlamalar ve frekans değerleri Tablo 2'de sunulmuştur. 
Tablo 2: Ders İçeriğinin Oluşturulması Teması Kategori ve Kodları

\begin{tabular}{cccc}
\hline Tema & Kategori & Kod & Frekans \\
\hline \multirow{3}{*}{ Ders içeriğinin oluşturulması } & YöK & Öğretmen yetiştirme lisans programı & 5 \\
\cline { 2 - 4 } & Akademik yayın & Ders kitabı & 1 \\
\cline { 2 - 4 } & Öğrenci & Öğrenci soruları & 1 \\
\hline
\end{tabular}

Tablo 2'ye göre öğretim üyelerinin görüşleri incelendiğinde YÖK'ün hazırladığı müfredata göre, Altun (2013) tarafından yazılan Eğitim fakülteleri ve sınıf öğretmenleri için matematik öğretimi kitabına göre derslerini şekillendirdiğini ifade etmiştir. Ayrıca YÖK müfredatını kullanan bir diğer öğretim üyesi ise ders esnasında konuya ilişkin öğrencilerden gelen sorulardan yola çıkarak da dersini tamamladığını dile getirmiştir.

YÖK kategorisinde, öğretmen yetiştirme lisans programı koduna ait öğretim üyesi görüşünü (ÖÜ6) “Mutlaka YÖK'ün öğretmenlik için hazırladığı programı inceliyorum. O ders kapsamında hangi konuların anlatılması gerekiyor. YÖK'ün müfredatına göre hangi konuların anlatılması gerekiyor. Önem sırasına göre ve birbiriyle ilişkili olma durumuna göre straya koyup o şekilde anlatıyorum" sözleriyle açıklamıştır. Akademik yayın kategorisinde, ders kitabı koduna ait öğretim üyesi görüşü (ÖÜ1) "Altun (2013) kitabındaki konu stralamasına göre ilerliyorum." biçimindedir. Öğrenci kategorisinde, öğrenci soruları koduna ait öğretim üyesi görüşü (ÖÜ5) "Normal bir programımız var onun akışı içerisinde karar veriyorum bir de öğrencilerin soruları varsa onlara mutlaka zaman ayırıyorum" şeklindedir.

Öğretim üyelerinin "Derse gitmeden önce anlatacă̆ınız konuları nasıl inşa ediyorsunuz?" sorusuna ilişkin verdiği yanıtların analizi ile elde edilen "Ders hazırlık süreçleri" temasına ait kodlamalar ve frekans değerleri Tablo 3'de sunulmuştur.

Tablo 3: Ders Hazırlık Süreçleri Temasına Ait Kategori ve Kodları

\begin{tabular}{cccc}
\hline Tema & Kategori & Kod & Frekans \\
\hline \multirow{3}{*}{ Ders hazırlık süreçleri } & Geçmiş deneyim & Matematiksel bilgiye dayalı deneyim & 3 \\
\cline { 3 - 4 } & & Pedagojik deneyim & 3 \\
\cline { 3 - 4 } & Akademik yayın & Akademik makale & 3 \\
\cline { 3 - 4 } & & Kendi yazdiğı ders kitapları & 1 \\
\cline { 3 - 4 } & & Ders kitabındaki etkinlikler & Google \\
\hline
\end{tabular}

$\mathrm{Bu}$ araştırma bağlamında öğretim üyelerinin görüşleri incelendiğinde geçmiş deneyimlerden alan ve pedagojik alan bilgisinden yararlandığını ifade etmiştir. Bazı öğretim üyeleri aktif olarak internetten öğretim içerikli videolar izlerken, Google’ı kullanarak araştırma yaptıklarını bazıları ise akademik yayınlardan faydalandıklarını dile getirmiştir. Derse gitmeden önce hazırlıklarını Altun (2013) tarafından yazılan ders kitaplarına bakarak inşa eden öğretim üyeleri de mevcuttur. Ders hazırlık süreci temasındaki kodlara ait öğretim üyelerinin görüşleri doğrudan alıntılara yer verilmiştir.

Geçmiş deneyim kategorisinde, matematiksel bilgiye dayalı deneyim koduna ait öğretim üyesi görüşü (ÖE2) “Genel olarak ben asistanken derse girdiğim için konulara sadece çoğu zaman böyle bir yüzeysel olarak bakıp girerim açıkçası. Yani eskiden gelen tecrübenin ışığında bir hatırlatma bağlamında bakarım" şeklindedir. Pedagojik deneyim koduna ait öğretim üyesi görüşü (ÖÜ6) "Çok uzun zamandır derslere girdiğim için ve dersler eş değer olduğu için zaten kafamda hazırlıklarım olmuş oluyor o yüzden ekstradan yenilenmişse kaynaklara bakıyorum internetten araştırmalar yapıyorum o şekilde öğrenciler için daha faydalı olacak materyalleri tasarlamaya ya da hazır materyaller varsa onları kullanmaya çalışıyorum ama çok aşırı materyal kullandığım söylenemez daha çok hani bunun faydalı olduğunu söylememize rağmen ne yazık ki sunuş yoluyla anlatıyoruz biz de internetten firsat buldukça göstermeye çalışıyorum" biçimindedir. Akademik yayın kategorisinde, akademik makale koduna ait öğretim üyesi görüşü (ÖÜ5) "Yenilikleri okuduğum makalelerden falan ekliyorum bir de şu son dönemlerde özellikle okuryazarlı soruların ve derse nasıl entegre edileceği üzerine tartışma açıyorum bu şekilde" ifade etmiştir. Ders kitabındaki etkinlikler koduna ait öğretim üyesi görüşü (ÖÜ1) "Murat hocanın özellikle sını öğretmeni adayları için hazırladığı kitap. Yani oradaki sıraya göre gidiyorum oradaki etkinlikleri kullanarak dersimi inşa ediyorum" 
biçimindedir. Kendi yazdığı ders kitapları koduna ait öğretim üyesi görüşü (ÖÜ5) "Daha çok kendi yazdığım ders kitapları ve ders notları var" şeklindedir. İnternet kategorisinde, Google koduna ait (ÖÜ3) "Rusya'daki kitaplara Google'dan bakıyorum. Eğer o ders bilgisayar algoritma dersi ise kendi kaynaklarımı kullanıyorum. Rusya'da hoca iken kendi yazdığım kitaplara göre anlatıyorum. Yazmadığım kitaba geldiğinde Google'dan bakıyorum. Zaten algoritma dersini kendim daha önce çalışmıştım o yüzden sadece kendi kaynaklarımı kullanıyorum o derste. Çalışmadığım derste Google'dan araştırıyorum konulara göre ne olmuş, ne bitmiş, nasıl anlatmış ona göre bakıyorum" biçiminde dile getirmiştir.

Öğretim üyelerinin "Anlattığını konular seneden seneye değişiyor mu? Anlattığını konularda ya da anlatım tarzınızda seneden seneye değişen farklılıklar var mıdır? Örneklendiriniz." sorusuna ilişkin verdiği yanıtların analizi ile elde edilen "Mesleki yaşantılar" temasına ait kodlamalar ve frekans değerleri Tablo 4'te sunulmuştur.

Tablo 4: Mesleki Yaşantılar Temasına Ait Kategori ve Kodları

\begin{tabular}{cccc}
\hline Tema & Kategori & Kod & Frekans \\
\hline \multirow{3}{*}{ Mesleki yaşantılar } & & Akademik literatüre göre değişiklik & 4 \\
\cline { 3 - 4 } & Değişiklik & Mesleki inanca göre değişiklik & 3 \\
\cline { 3 - 4 } & & Öğrenci hazırbulunuşluklarına göre değişiklik & 2 \\
\cline { 2 - 4 }
\end{tabular}

$\mathrm{Bu}$ araştırma bağlamında öğretim üyelerinin görüşleri incelendiğinde hepsi seneden seneye anlatılan konularda ve anlatım tarzlarında değişiklik yaptıklarını belirtmişlerdir. Öğretim üyelerinin çoğu akademik literatürü baz alarak yapılan değişikleri ifade ederken; mesleki inanca göre yapılan değişikliklerin de çoğu tarafından ifade edildiği görülmektedir. ÖÜ5 kodlu öğretim üyesinin öğrencilerin hazırbulunuşluklarına ve yenilikçilik anlayışına göre yapılan değişikleri ifade ettiği görülmektedir.

Mesleki yaşantılar temasındaki kodlara ait öğretim üyelerinin görüşleri doğrudan alıntılara yer verilmiştir. Değişiklik kategorisinde, akademik literatüre göre değişiklik kodundaki öğretim üyesine ilişkin görüşü (ÖÜ3) "Her zaman değişiyor. Seneden seneye de değiş̧iyor. Dönemden döneme de değisşiyor. Konular değil de konu içerikleri değişiyor, konular değişmiyor" biçimindedir. Mesleki inanca göre değişiklik kodundaki öğretim üyesine ilişkin görüşü (ÖÜ4) "Güncelleme anlamında yüzde 10-15 şeklinde değişebiliyor ama genel kalıp değişmiyor. Anlatım tarzı olarak tabi ki insan değişken insandır ve değişen yapıya uygun anlatım tarzı yöntemleri tercih etmeye göre değiştiriyoruz" diye dile getirmiştir. Öğrenci hazırbulunuşluklarına göre değişiklik kodundaki öğretim üyesinin görüşü (ÖÜ3) “Öğrencilerin tepkilerinden etkilenirim ve öğrenci memnuniyetini yani matematik doyum sağlamasını dikkate alırım anlam bilgisini çok dikkate alırım" diye ifade etmiştir. Yenilikçilik kodundaki öğretim üyesinin görüşü (ÖÜ5) "Beraber yıldan yıla devinen bir anlatımım var yani şu anda ileri bir tecrübe noktasında olmama rağmen bu yıl anlattı̆̆ım ders geçen yıldan farklıdır ama daima yenilikçidir yani on sene önce de yenilikçidir bu yılda yenilikçidir yeni sentezler var olan bir metodoloji bilgisi var bir de yenilik geliyor buna bir de kendim çok yerelleştiririm yabancı yazıları yerelleştirmek suretiyle modernize ederim yani olduğu gibi hiç bir zaman almam kendi fikrimle birleştiririm mutlaka tecrübeyle birleştiririm öğrencilerin tepkilerinden etkilenirim"şeklindedir.

Öğretim üyelerinin derslerinin zaman içinde şekillendirilmesi ile ilgili yaptıkları değişimleri aldıkları kaynaklar ile ilgili soruya verdikleri cevapların analizi sonucunda oluşturulan "Kaynak sistemleri" temasına ait kodlamalar ve frekans değerleri Tablo 5 'te sunulmuştur.

Tablo 5: Kaynak Sistemleri Temasına Ait Kategori ve Kodları

\begin{tabular}{|c|c|c|c|}
\hline Tema & Kategori & Kod & Frekans \\
\hline \multirow{7}{*}{ Kaynak sistemleri } & Akademik yayın & Akademik kitap & 6 \\
\hline & Geçmiş deneyim & Kişisel deneyim & 2 \\
\hline & \multirow{2}{*}{ Öğrenci } & Öğrenci ifadeleri & 2 \\
\hline & & Öğrenci dönütleri & 1 \\
\hline & Ders materyali & Bilgisayar uygulamaları & 1 \\
\hline & \multirow{2}{*}{ Matematik } & Matematiğin doğası & 1 \\
\hline & & Yaşamsallaştırma & 1 \\
\hline
\end{tabular}


$\mathrm{Bu}$ araştırma kapsamında öğretim üyelerinin görüşleri incelendiğinde öğretim üyelerinin hepsi akademik kitaplardan yararlanarak değişimleri aldıklarını ifade etmişlerdir. Bazı öğretim üyeleri öğrenci ifadelerine göre değişimlerini yaptıklarını belirtirken öğretim üyelerinden bir tanesi öğrenci dönütlerine göre değişim yaptığını dile getirmiştir. Öğretim üyelerinden bazıları kişisel deneyimlerinden yola çıkarak değişim yaptıklarını belirtmiştir. Öğretim üyelerinden bir tanesi değişimlerini bilgisayar aplikasyonlarına göre yaptığını söylemiştir. Bir diğer öğretim üyesi matematiğin doğası ve yaşamsallaştırmayı dikkate alarak değişimler yaptı̆̆ını dile getirmiştir.

Kaynak sistemleri temasındaki kodlara ait öğretim üyelerinin görüşlerine yönelik doğrudan alıntılara yer verilmiştir. Akademik yayın kategorisinde, akademik kitap koduna ait öğretim üyesi görüşü (ÖÜ2) “Değişimleri genellikle yabancı kaynaklardan alıyorum. Dersine göre, konusuna göre diferansiyel denklemler ise "Differential Equations" diye yabancı kaynak var onu kullanıyorum. Veya lineer cebir ise "Linear Algebra" diye kaynağa bakarım. Bazen de az olmasına rağmen Türkçe kaynaklara ihtiyaç duyuyoruz. Ona da bakarım" şeklinde ifade etmiştir. Geçmiş deneyim kategorisinde, kişisel deneyim koduna ait öğretim üyesi görüşü (ÖÜ5) “Daha çok kendi sentezlerim: bir matematiğin doğasından etkileniyorum iki yaşamsallaştırma çok önemli şu anda. Sentezler, var olan bir metodoloji bilgisi var bir de yenilik geliyor buna bir de kendim çok yerelleştiririm yabancı yazıları yerelleştirmek suretiyle modernize ederim yani olduğu gibi hiçbir zaman almam kendi fikrimle birleştiririm mutlaka tecrübeyle birleştiririm" biçimindedir. Öğrenci kategorisinde, öğrenci ifadeleri koduna ait öğretim üyesi görüşü (ÖÜ3) “Birebir hiçbir kaynağı izlemiyorum. Kendim oluşturuyorum o konunun içeriğini nasıl vereceğim diye, ona göre devam ediyorum. Hem kendi perspektifimden hem de çocukların perspektiflerinden yararlanıyorum. Kendi tecrübelerime dayanarak değişimleri yapıyorum" biçiminde dile getirmiştir. Öğrenci dönütleri koduna ait öğretim üyesi görüşü (ÖÜ5) “öğrencilerin tepkilerinden etkilenirim ve öğrenci memnuniyetini yani matematik doyum sağlamasını dikkate alırım anlam bilgisini çok dikkate alırım benim derslerimin en fazla fark edileni olur bir soru sorarım mesela hesaplamak yerine kendi aralarında tartışı cevaplayabilecekleri konunun anlamını ortaya çıkarabilecekleri sorularım olur" diye ifade etmiştir. Ders materyali kategorisinde, bilgisayar aplikasyonu koduna ait öğretim üyesi görüşü (ÖÜ1) “Dediğim gibi bilgisayar aplikasyonu da olabiliyor. Rastladığım bilgisayar oyunu da oluyor" biçimindedir. Matematik kategorisinde, matematiğin doğası koduna ait öğretim üyesine ait görüş (ÖÜ5) "Matematiğin doğasından etkileniyorum." şeklindedir. Yaşamsallaştırma koduna ait öğretim üyesi görüşü (ÖÜ5) "Yaşamsallaştırma çok önemli şu anda" diyerek açıklamada bulunmuştur.

Öğretim üyelerinin "Sizi en çok etkileyen kaynak, nesne nedir ya da kişi kimdir? Nedenlerini açıklayınız." sorusuna ilişkin verdiği yanıtların analizi ile elde edilen "İlham kaynağı" temasına ait kodlamalar ve frekans değerleri Tablo 6'da sunulmuştur.

Tablo 6: İlham Kaynağı Temasına Ait Kategori ve Kodları

\begin{tabular}{|c|c|c|c|}
\hline Tema & Kategori & Kod & Frekans \\
\hline \multirow{8}{*}{ İlham kaynağ } & \multirow[t]{2}{*}{ Akademik yayın } & Akademik kitap & 3 \\
\hline & & Ders kitabı & 4 \\
\hline & \multirow{3}{*}{ İnternet } & Google akademik & 1 \\
\hline & & Öğretim içerikli videolar & 1 \\
\hline & & Sinema filmi & 1 \\
\hline & Akademik etkinlik & Bilimsel toplantı & 1 \\
\hline & \multirow{2}{*}{ Rol- model aldığı kişi } & Üniversitedeki öğretim üyeleri & 3 \\
\hline & & Lisedeki tarih öğretmeni & 1 \\
\hline
\end{tabular}

Bu araştırma kapsamında öğretim üyelerinin görüşleri incelendiğinde öğretim üyelerinin yarısını en çok etkileyen kaynakların akademik kitaplar olduğu belirtilmiştir. Öğretim üyeleri ayrıca ders kitaplarından da sıkça faydalandıklarını belirtmişlerdir. Öğretim üyelerinden bir tanesi en çok etkileyen kaynağın Altun'un (2013) ders kitabı olduğunu söylerken bir diğer öğretim üyesi en çok etkileyen kaynağın Altun (2015), Baykul (2014) ve Baki'nin (2015) ders kitapları olduğunu dile getirmiştir. Öğretim üyelerinden bir tanesini en çok etkileyen kaynağın sinema filmi olduğunu ifade ederken bir başka öğretim üyesi öğretim içerikli videolardan ve Google akademikten etkilendiğini belirtmiştir. Öğretim üyelerinden bir tanesi mesleki deneyimlerinden etkilendiğini ifade ederken bir

| Manisa Celal Bayar University Journal of The Faculty of Education, 2021, Vol. 9, No. 1 | 
başka öğretim üyesi kişisel deneyimlerinden etkilendiğini dile getirmiştir. Öğretim üyelerinin yarısını en çok etkileyen kişinin üniversitedeki öğretim üyeleri olduğunu belirtirken üniversitedeki öğretim üyelerinden etkilenen bir öğretim üyesi ayrıca lisedeki tarih öğretmenin öğretmenlik tarzından etkilendiğini belirtmiştir.

İlham kaynağı temasındaki kodlara ait öğretim üyelerinin görüşleri doğrudan alıntılara yer verilmiştir. Akademik yayın kategorisinde, akademik kitap koduna ait öğretim üyesi görüşü (ÖÜ4) “Kaynak derken kitaplar yanı sıra ulaşılabilirlik yönünden internet kaynakları ve bazen de çeşitli uluslararası eğitim kurumlarının yapmış olduğu videoları seyretmeyi seviyorum bu üçlemeyi yani kitap internetteki araştırma ve videolarn üçlemesinden mutlaka etkilenerek devam ediyorum. Karışık kaynaklara değer veriyorum yani Türkçe ve yabancı, çünkü Türkçe kaynakların da değerli olanları var bazen anlaşılırı anlatmayabiliyor kaynaklar o zaman yabancı kaynaklardan da destek alabiliyorum ama hiçbir zaman şu iyidir şu kötüdür diye hiçbir kaynağa bă̆lı kalmıyorum" ifadelerine yer vermiştir. Ders kitapları koduna ait öğretim üyesi görüşlerinden bir tanesi (ÖÜ1) "En çok etkileyen kaynak Murat hocanın sımı öğretmeni adaylar için yazdığı matematik öğretimi kitabı" biçimindedir. Ders kitapları kodu ile ilgili bir diğer öğretim üyesi görüşünü (ÖÜ6) "Birçok hocamızın kitapları var. Adnan hocamızın Murat hocamızın Yaşar Baykul'un kitapların kullanıyorum hepsinin belli özelliklerinden faydalanıyorum nedenleri de hangi konu hangi kitapta daha iyi örneklendirilmiş bunlar benim için önemli işime ne yarıyorsa ona göre kullanıyorum" ifadeleri ile dile getirmiştir. İnternet kategorisindeki Google akademik koduna ilişkin öğretim üyesinin görüşü (ÖÜ4) "ulaşılabilirlik yönünden internet kaynaklarından mutlaka etkilenerek devam ediyorum. Google akademik taramayı yaparım şu site bu site diye bir şey yok o anda konu beni nereye itiyorsa ordan araştırma yapryorum yani kalıp yok" şeklinde ifade etmiştir. İnternet kategorisindeki öğretim içerikli videolar koduna ilişkin öğretim üyesinin görüşü (ÖÜ4) "Çeşitli uluslararası eğitim kurumlarının yapmış olduğu videoları seyretmeyi seviyorum" biçimindedir. İnternet kategorisindeki sinema filmi koduna ilişkin öğretim üyesinin görüşü (ÖÜ1) "Dediğim gibi farkl kaynaklara döneceğim tekrar ama bazen bir sinema filmi de olabiliyor kullandığım kaynak, etkilendiğim şey" diye dile getirmiştir. Akademik etkinlik kategorisindeki bilimsel toplantı koduna ilişkin öğretim üyesinin görüşü (ÖÜ5) "YÖK dünya bankası çerçevesinde gönüllü olarak katıldı̆̆ım paneller beni etkilenmiştir 1997 senesinde o beni çok etkilemiştir çok çalışanı vardı ama ben orda yabancılarla tartıştıklarımızı üniversitemde uygulayarak sonuçlarımı bu panellere taşımışımdır ve çok yararın görmüşümdür" biçimindedir. Rol- model aldığı kişi kategorisindeki üniversite hocaları koduna ilişkin öğretim üyesinin görüşü (ÖÜ3) "Beni en çok üniversite hocalarım etkilemiştir. Çünkü onlardan birçok şeyi aldım. Anlatım tarzını aldım" diye ifade etmiştir. Rol- model aldığı kişi kategorisindeki Lisedeki tarih öğretmeni koduna ilişkin öğretim üyesinin görüşü (ÖÜ5) “Lisedeki tarih öğretmeni öğretmenlik tarzı olarak o" diye ifade etmiştir.

\section{TARTIŞMA, SONUÇ ve ÖNERILER}

$\mathrm{Bu}$ araştırmada öğretim üyelerinin öğretim sürecinde kullandıkları kaynakların incelenmesi amaçlanmıştır. Bu kapsamda matematik eğitimi anabilim dalındaki altı öğretim üyesi ile gerçekleştirilen araştırma sonucunda öğretim üyelerinin ders içeriğinin oluşturulma, ders hazırlık süreçleri, mesleki yaşantılar, kaynak sistemleri ve ilham kaynakları belirlenmiştir. Öğretim üyeleri öğretim sürecinde ders içeriğini oluştururken YÖK'ün hazırladığ1 müfredatı, eğitim fakülteleri ve öğretmenler için yazılan ders kitaplarını, öğrenci ifadelerini kullandığını dile getirmiştir. Bu sonuç, Sezer (2020) öğretim üyesinin öğretim sürecinde belli bir kaynağı sistematik olarak takip ettiğini ve öğrenci düzeyi, öğrenci ihtiyaçları, öğrenci motivasyonunu dikkate aldığı sonucu ile paralellik göstermektedir.

$\mathrm{Bu}$ araştırma sonucunda öğretim üyeleri ders hazırlık süreçlerinde geçmiş deneyimlerden, alan ve pedagojik alan bilgisinden, aktif olarak internetten öğretim içerikli videolardan, Google'ı kullanarak yaptıkları araştırmalardan ve akademik yayınlardan faydalandıkları sonucuna ulaşılmıştır. Öğretmenlerin farklı kaynaklardan oluşturdukları dokümanları ders hazırlık sürecinde kullanmaları Gueudet ve Trouche'un (2010) çalışması ise paralellik göstermekte olup bu sürecin karmaşıklığı kullanılan kaynakların çeşitliliği ile artmaktadır. Ayrıca ders hazırlık sürecinde kendi yazdığı ders kitabını kullanan öğretim üyesinin de olduğu görülmüştür. Bu araştırma sonucuna paralel olarak Agaç (2018) öğretim üyelerinin bilgi kaynağını kendi deneyim temelleri üzerine inşa ettiği sonucuna ulaşan çalışmalar mevcuttur. Diğer taraftan van Veen (2013) öğretim üyelerinin kendi gerçekleştirmiş olduğu çalışmalarının ve 
alanyazında yer alan araştırmalara ilişkin okumaların bilgi kaynağı olduğunu dile getirmiştir. Bu bağlamda Özmantar ve diğerleri (2017) öğretmenlerin büyük bir çoğunluğunun ders kitabını kaynak olarak kullandığı sonucu ve Altun, Arslan ve Yazgan (2004) öğretmenlerin ders sürecinde ders kitabını kaynak olarak kullandığı sonucu ile bu araştırmanın ders hazırlık sürecinde kendi yazdığı ders kitabını kullanan öğretim üyesinin olması sonucu örtüşmektedir. Ayrıca Agaç (2018) öğretim üyelerinin bilgi kaynağı olarak internet kaynaklarını kullandıklarını tespit etmiştir. Tapan-Broutin ve Ilkorucu (2018) lisansüstü öğrencisi öğretmenler ile yaptığı çalışmada da internet kaynaklarının öğretmenler tarafından doküman olarak kullanıldığını göstermiştir. Bu sonuçlar, bu araştırmanın öğretim üyelerinin ders hazırlık sürecinde deneyim ve internet kaynaklarını kullandığı sonucunu destekler niteliktedir. Buna karşın Mustafa ve Şahin (2013) 2010-2011 eğitim-öğretim yılında öğretim üyelerinin öğretim amaçlı internet kullanımlarının "bazen" olduğu sonucuna ulaşmıştır. Bunun sebebi bu araştırmanın 2010-2011 eğitimöğretim yılında yapılmış olup o yıllarda interneti kaynak olarak kullanmanın yaygın olmaması olabilir.

$\mathrm{Bu}$ araştırma sonucunda öğretim üyelerinin mesleki yaşantılarında seneden seneye anlatılan konularda ve anlatım tarzlarında değişiklik yaptığı ve bu değişiklikleri akademik literatüre ve mesleki inanca, öğrencilerin hazırbulunuşluklarına ve yenilikçilik anlayışına göre yaptığı sonucuna ulaşılmıştır Benzer şekilde Sezer (2020) öğretim üyesinin ders planını yıllara veya öğrencilere göre değiştirdiğini ve ders içeriğini akademik çalışmalar ile internet araştırmalarına göre güncellediğini tespit etmiştir. Bu sonuç, öğretim üyelerinin seneden seneye anlatılan konularda ve anlatım tarzlarında değişiklik yaptığı sonucunu destekler niteliktedir.

$\mathrm{Bu}$ araştırma sonucunda öğretim üyelerinin mesleki yaşantılardaki değişimleri akademik kitaplardan, öğrenci ifade ve dönütlerinden, kişisel deneyimlerinden, bilgisayar uygulamalarından, matematiğin doğası ve yaşamsallaştırmadan aldığını belirtmiştir. Benzer şekilde Sezer (2020) öğretim üyesinin öğretim sürecinde kaynak kullanımına ilişkin değişimlerini tecrübe, akademik araştırmalar, internet araştırmaları, öğrenci düzeyi, öğrencilerin ihtiyaçları, öğrenci motivasyonuna göre güncellediğini belirtmiştir. $\mathrm{Bu}$ sonuç, bu araştırmanın sonucuyla örtüşmektedir.

Bu araştırma sonucunda öğretim üyelerini en çok etkileyen kaynaklar tercih edilme durumuna göre akademik kitaplar, sinema filmi, öğretim içerikli video, Google akademik, bilimsel toplantı olduğu sonucuna ulaşılmıştır. Öğretim üyelerini en çok etkileyen kişinin üniversitedeki öğretim üyeleri olduğu bulunmuştur. Benzer şekilde Agaç (2018) öğretim üyelerinin bilimsel toplantıları bilgi kaynağı olarak kullanıldığı sonucuna ulaşmıştır. Ayrıca Taylor (2011) öğretim üyelerinin, öğretmen adaylarının pedagojik alan bilgisini artırmak amacıyla kullanmış olduğu bilgi kaynaklarının mesleki okumalar ve kongreler olduğu sonucuna ulaşmıştır. Benzer şekilde Lorist, Swennen ve White (2017) öğretim üyelerinin mesleki faaliyetlerin bilgi kaynağı olarak kullandığını tespit etmiştir. Bu sonuçlar, bu araştırmanın öğretim üyelerinin kaynaklarının Google akademik, bilimsel toplantı vb. olması sonuçlarıyla paralellik göstermektedir.

$\mathrm{Bu}$ araştırmada eğitim fakültesinde derslere giren öğretim üyelerinin öğretim sürecinde kullandıkları kaynaklar incelenmiştir. Benzer şekilde lisans eğitiminin son sınıfında olan öğretmenlik deneyimi dersini alan öğretmen adayları ile öğretmenlerin doküman oluşturma süreçlerini ve öğretim sürecinde kullandıkları kaynaklara ilişkin görüşlerini inceleyen araştırmalar yapılması önerilir.

Ayrıca bu araştırma, öğretim üyelerinin kaynak kullanımlarına yönelik beyanları ile sınırlı kalmışır. Daha kapsamlı bir çalışma ile öğretim üyelerinin derslerini hazırlama süreçleri, ders içi davranışları ve ders sonrası düzenleme süreçleri de incelenebilir. Öğretim üyelerinin hangi kaynağı hangi sebeple reddedip hangi sebeple kabul etme kriterleri incelenebilir.

Türkçe, İngilizce, sosyal bilgiler, fen bilgisi, müzik gibi farklı disiplinlerdeki öğretim üyelerinin ders içeriklerini oluşturma süreçleri, ders hazırlık süreçleri ve bilgi kaynakları disiplinlerarası karşılaştırmalı olarak incelenebilir. Ayrıca farklı ülkelerdeki öğretim üyelerinin öğretim sürecinde kullandıkları kaynaklar ve bu kaynaklara ilişkin görüşleri incelenebilir. 
KAYNAKÇA

Adler, J. (2000). Conceptualising resources as a theme for teacher education. Journal of Mathematics Teacher Education, 3, 205-224.

Agaç, G. (2018). Etkili matematik öğretimine ilişkin öğretim elemanlarının perspektifleri ve bilgi kaynakları üzerine bir inceleme. (Yayımlanmamış Doktora Tezi). Gaziantep Üniversitesi Eğitim Bilimleri Enstitüsü, Gaziantep.

Altun, M., Arslan, Ç., ve Yazgan, Y. (2004). Lise matematik ders kitaplarının kullanım şekli ve sıklığı üzerine bir çalışma. Uludă̆ Üniversitesi Ĕ̆̈itim Fakültesi Dergisi, 17(2), 131-147.

Altun, M. (2013). Eğitim fakülteleri ve sınıföğretmenleri için matematik öğretimi. (18. Bask1). Bursa: Alfa Kitabevi.

Altun, M. (2015). Ortaokullarda matematik öğretimi. (12.Baskı). Bursa: Alfa Kitabevi.

Association of Mathematics Teacher Educators (AMTE). (2017). Standards for Preparing Teachers of Mathematics. https://amte.net/sites/default/files/SPTM.pdf

Baki, A. (2015). Kuramdan uygulamaya matematik eğitimi. (6. Baskı). Ankara: Harf Eğitim Yayıncılı̆̆1.

Baştürk-Şahin, B. N. (2015). İlköğretim matematik öğretmenlerinin ders dokümanı hazırlama süreçlerinin incelenmesi. (Yayınlanmamış Yüksek Lisans Tezi). Uludağ Üniversitesi Eğitim Bilimleri Enstitüsü, Bursa.

Baştürk-Şahin, B. N., \& Tapan-Broutın, M. S. (2018). Analysis of primary mathematics teachers' lesson document preparation processes. In Proceedings of the Re(s)sources 2018 International Conference, (s. 48-52). Lyon.

Baykul, Y. (2014). Ortaokulda matematik öğretimi (5-8. Sinıflar). (2. Baskı). Ankara: Pegem Yayıncılık.

Cohen, D. K., Raudenbush, S. W., \& Ball, D. L. (2003). Resources, instruction, and research. Educational Evaluation and Policy Analysis, 25(2), 119-142.

Council for the Accreditation of Educator Preparation. (2019). 2013 CAEP standards. http://www.ncate.org/ /media/Files/caep/standards/caep-standards-one-pager-0219.pdf?la=en

Çepni, S. (2018). Araştırma ve proje çalışmalarına giriş. (8.Baskı). Trabzon: Celepler Matbaacılık.

Gözalan-Çiçek, F. (2016). Eğitim fakültelerindeki öğretmen eğitimcilerinin genel alan yeterlilikleri. (Yayınlanmamış Doktora Tezi). Gazi Üniversitesi Eğitim Bilimleri Enstitüsü, Ankara.

Gueudet, G., \& Trouche, L. (2010). Ressources vives. Le travail documentaire des professeurs en mathématiques. Lectures, Publications reçues.

Işık-Sarıoğlu, B. (2020). Matematik öğretmenlerinin aday öğretmenken ve meslek hayatları esnasında dokümantal oluşum süreçlerinin incelenmesi. (Yayınlanmamış Yüksek Lisans Tezi). Bursa Uludağ Üniversitesi Eğitim Bilimleri Enstitüsü, Bursa.

Lorist, P., Swennen, A., \& White, E. (2017). Life and work of teacher educators, volume 4: Teacher educators pathways to becoming research active. HU University of Applied Sciences Utrecht.

Merriam, S. B. (1998). Qualitative research and case study applications in education. Revised and expanded from "case study research in education". San Francisco, CA: Jossey-Bass Publishers.

Millı̂ Eğitim Bakanlığı (MEB). (2008). Öğretmen yeterlikleri: Öğretmenlik mesleği genel ve özel alan yeterlikleri. Ankara: Millî Eğitim Bakanlığ Öğretmen Yetiştirme ve Eğitimi Genel Müdürlüğü.

Millî Eğitim Bakanlığı (MEB). (2017). Öğretmenlik mesleği genel yeterlikleri. Ankara: Millî Eğitim Bakanlı̆̆ı Öğretmen Yetiştirme ve Eğitimi Genel Müdürlüğü.

Mustafa, M. Q., \& Şahin, S. (2013). Öğretim elemanların öğretim amaçlı internet kullanımları. Eğitim Teknolojisi Kuram ve Uygulama, 3(1), 1-12.

National Board for Professional Teaching Standards (NBPTS). (2016). Mathematics standards. http://www.nbpts.org/wp-content/uploads/EAYA-MATH.pdf 
Özmantar, M. F., Dapgın, M., Çırak- Kurt, S., \& İlgün, Ş. (2017). Matematik öğretmenlerinin ders kitabı dışında kaynak kullanımları: nedenler, sonuçlar ve çıkarımlar. Gaziantep University Journal of Social Sciences, 16(3), 741758.

Pepin, B., Gueudet, G., \& Trouche, L. (2013). Re-sourcing teachers' work and interactions: a collective perspective on resources, their use and transformation. ZDM-The International Journal on Mathematics Education, 45(7), 929-943.

Sezer, E. (2020). İlköğretim matematik öğretmenliği lisans programlarında alan eğitimi derslerinin özel alan yeterliklerini kazandırması yönünden değerlendirilmesi. (Yayımlanmamış Doktora Tezi). Uludağ Üniversitesi Eğitim Bilimleri Enstitüsü, Bursa.

Tapan-Broutın, M. S. (2017). Ortaokul matematik öğretmen adaylarının internet ortamındaki kaynakları kullanım düzeylerinin incelenmesi. Uludă̆ Üniversitesi Eğitim Fakültesi Dergisi, 30(2), 861-880.

Tapan-Broutın, M. S., \& Ilkorucu, S. (2018). Different types of resources used by master students considering their thinking styles. Journal of Education and Training Studies, 6(11), 11-20.

Taylor, C. E. (2011). Facilitating the development of elementary prospective teachers' pedagogical content knowledge: A case study of a mathematics teacher educator's actions and purposes. (Unpublished Doctoral Dissertation). University of Missouri, Columbia.

van Veen, K. (2013). The knowledge base of teacher educators: the nature, dilemmas, and challenges. In M. BenPeretz (Ed.), Teacher educators as members of an evolving profession. Lanham: Rowman and Littlefield.

Yıldırım, A., \& Şimşek, H. (2008). Sosyal Bilimlerde Nitel Araştırma Yöntemleri, (6.Baskı). Ankara: Seçkin Yayıncılık.

Yin, R. K. (2003). Case study research: Design and methods. Applied Social Research Methods Serial, 5 (3rd ed.). 
Extended Abstract

\section{Introduction}

In this study, the elements that affect the process of creating the course content of the faculty members in the field of mathematics and mathematics education were examined. In this context, the problem of the research is "What are the resources in the process of creating the course content of the lecturers in the field of mathematics and mathematics education?" constitutes the question.

\section{Method}

In this study, the case study method, one of the qualitative research designs, was used in order to examine the resources used by the faculty members in the teaching process. The case study allows for in-depth examination of a subject under investigation and is a preferred method in understanding various issues of education, especially in seeking answers to what, how and why questions (Çepni, 2018; Merriam, 1998; Yin, 2003). The state of this research is the resources that faculty members use in their teaching process.

The working group of the research consists of six faculty members working in the department of mathematics education in a state university education faculty in the Marmara Region in the spring semester of the 2018-2019 academic year. Typical case sampling, one of the purposeful sampling methods, was used in this study. The purpose of typical case sampling is to have an idea about a particular area by studying average cases (Yıldırım \& Şimşek, 2008).

Semi-structured interviews were used to obtain data in this study. In this context, since this study aims to examine and reveal the resources used by faculty members in the teaching process, semi-structured interviews were preferred for data collection.

Content analysis technique was used to analyze the data obtained in this study. The codes created are combined in appropriate themes and presented in tables.

\section{Findings}

1. When the opinions of the faculty members were examined, he stated that he shaped his lessons according to the curriculum prepared by YÖK, according to the mathematics teaching book for education faculties and classroom teachers written by Altun (2013). In addition, another faculty member using the YÖK curriculum stated that he completed his course based on the questions from the students regarding the subject during the course.

2. When the opinions of the faculty members were examined, he stated that they made use of pedagogical field knowledge, actively using videos with educational content from the internet, using Google and academic publications. There are also faculty members who build their preparations by looking at the textbooks written by Altun (2013) before they go to class. Direct quotations of the opinions of the faculty members regarding the codes in the course preparation process are included.

3. When the opinions of the faculty members were examined, they stated that they made changes in the subjects and their expression styles from year to year. He stated that the faculty members made the changes according to the academic literature and professional beliefs, respectively. In addition, it is seen that the ÖÜ5 coded faculty member expresses the changes made according to the readiness of the students and the understanding of innovation.

4. When the views of faculty members were examined, faculty members stated that the changes in shaping their lessons over time were academic books, student expressions, student feedback, personal experiences, computer applications, the nature of mathematics and vitalization.

5. When the views of faculty members are examined, the most influencing sources are academic books, textbooks, Altun (2013), Altun (2015), Baykul (2014) and Baki's (2015) textbooks, motion pictures, videos with teaching content, Google academic. , professional experiences and personal experiences. While he stated that the person who most affected the faculty members was the faculty members at the university, a faculty member who 
was influenced by the faculty members at the university also stated that he was influenced by the teaching style of the history teacher in high school.

\section{Result and Discussion}

Faculty members stated that they used the curriculum prepared by YÖK, textbooks written for education faculties and teachers, and student expressions while creating the course content in the teaching process. This result is in line with the result that Sezer (2020) faculty systematically follows a certain resource in the teaching process and takes into account student level, student needs, and student motivation.

The use of documents created by teachers from different sources in the course preparation process is parallel to the work of Gueudet and Trouche (2010), and the complexity of this process increases with the variety of resources used.

As a result of this research, it was concluded that faculty members made changes in their professional lives from year to year in the subjects and their expression styles, and made these changes according to the academic literature and professional belief, students 'readiness and innovation understanding. Similarly, Sezer (2020) faculty members' lesson plan according to years or students. and updated the course content according to academic studies and internet researches. This result supports the conclusion that faculty members make changes in the subjects and their style of expression from year to year.

As a result of this research, he stated that the faculty members took the changes in their professional lives from academic books, student expressions and feedback, personal experiences, computer applications, the nature of mathematics and vitalization. Similarly, Sezer (2020) stated that the faculty member updated the changes regarding the use of resources in the teaching process according to experience, academic research, internet research, student level, students' needs, and student motivation. This result coincides with the result of this research.

As a result of this research, it has been concluded that the sources that affect the faculty members the most are academic books, motion pictures, video with teaching content, Google academic, scientific meetings, depending on the preference. It has been found that the most influential person on faculty members is the faculty members of the university. Similarly, Agaç (2018) concluded that faculty members' scientific meetings were used as a source of information.

\section{Araştırmanın Etik Taahhüt Metni}

Yapılan bu çalışmada bilimsel, etik ve alıntı kurallarına uyulduğu; toplanan veriler üzerinde herhangi bir tahrifatın yapılmadığı, karşılaşılacak tüm etik ihlallerde "Manisa Celal Bayar Üniversitesi Eğitim Fakültesi Dergisi ve Editörünün" hiçbir sorumluluğunun olmadığı, tüm sorumluluğun Sorumlu Yazara ait olduğu ve bu çalışmanın herhangi başka bir akademik yayın ortamına değerlendirme için gönderilmemiş olduğu sorumlu yazar tarafından taahhüt edilmiştir. 